\title{
Asymmetric farm retail price movements in the Malaysian poultry market
}

\begin{abstract}
The relationship between farm, wholesale, and retail prices provides insight into marketing efficiency including the welfare of both consumers and farmers. Investigating the price transmission process at different levels in the marketing channel is crucial in assessing the market efficiency in poultry meat and egg subsectors in Malaysia. Changes in the farm or wholesale price could lead to changes in retail prices asymmetrically and this might distort the poultry and egg markets. This study applied the error correction model of price transmission for the entire poultry meat and egg value chain. The test was carried out using retail and farm monthly price data of poultry meat and eggs from 2000 to 2007. Empirical results suggest that the farm and retail price transmission process for the poultry and egg market is asymmetric. Price transmission estimates with rising farm prices generally are larger than corresponding estimates associated with falling farm prices.
\end{abstract}

Keyword: Error correction model (ECM); Poultry subsector; Price asymmetry; Retail and farm prices 